\title{
THE STRUGGLE FOR SPIRITUAL AUTHORITY FROM THE HOLY LAND TO INDONESIA: REFERENCE FROM THE TAREKAT NAQSHABANDIYYA JABAL HINDI (TNJH) IN NORTH SUMATRA
}

\author{
Uqbatul Khoir Rambe \\ State Islamic University of North Sumatra, Indonesia \\ E-mail: ukrambe@gmail.com \\ Nurliana Damanik \\ State Islamic University of North Sumatra, Indonesia \\ E-mail: nurlianadamanik15@gmail.com \\ Aprilinda M Harahap \\ State Islamic University of North Sumatra, Indonesia \\ E-mail: aprilinda@gmail.com
}

\begin{abstract}
This article discusses the struggle for spiritual authority between Sulaymān al-Zuhdī as "Shaykh Jabal Abi Qubais" and Khalil Hamdi Basya as "Shaykh Jabal Hindi." The conflict occurred in several stages from the beginning, and finally, Hamdi Basya moved on to Sulaymān al-Zuhdī. Although this clash of the leadership in the Tarekat Naqshabandiyya Khālidiyya (TNK) occurred in the holy land in Mecca, it also influences Indonesia. While the Tarekat Naqshabandiyya Jabal Abi Qubis (TNJAQ) network is barely found in Indonesia, the trail of the Tarekat Naqshabandiyya Jabal Hindi (TNJH) was encountered. By analyzing through a historical approach and interviewing several authoritative individuals, the research discovered that $\mathrm{TNJH}$ has been developing in Indonesia, especially in North Sumatra, and has widely spread within some areas, particularly Medan, Binjai, and Deli Serdang. It was also found that this Sufi order primaries the balance of dhikr al-qalb and dhikr al-'aql by mentioning Allah and paying attention to the creation in the process of tazkiyat al-nafs.
\end{abstract}

Keywords: Mecca, Indonesia, the Tarekat Naqshabandiyya Jabal Hindi, Jabal Abi Qubis, Jabal Hindi. 


\section{Introduction}

The Tarekat Naqshabandiyya is a tarekat associated with Muḥammad b. Muḥammad Bahā’ al-Dīn al-Uwaish al-Bukhārī alNaqsyabandī (1318-1389). He was born in the village of Qasr al'Arifan, which is about four miles from Bukhārā, which is also the birthplace of the prominent hadith narrator Imam al-Bukhari. ${ }^{1}$ The word "Naqshbandi" comes from Arabic, which consists of two words, "naqsh" and "band." "Naqsh" means an engraving or picture, while “band" means a flag or big screen. So, Naqshabandiyya (Naqsyabandiyyah in Indonesia) can be interpreted as a carving or image attached to a flag or screen, such as a flag or large banner. It is called Naqshabandiyya because of the dhikr activity carried out in it as an effort to carve or draw Allah's words in the heart so that they are not separated in all the activities that are carried out. Naqshabandiyya, as a form of carving or image, also refers to Shaykh Bahā' al-Dīn, who is always on remembrance all the time. So, that Allah pronunciation is engraved in his heart. ${ }^{2}$

The Tarekat Naqshabandiyya was originally developed in Bukhara around the $14^{\text {th }}$ century and continued to develop outside the area due to the then ruler support, the Dynasty of Timuriyya. The intimate relationship between the leadership of the Tarekat Naqshabandiyya and the rulers provided wide space for the expansion of the tarekat beyond the borders between countries. It fully supported it because of the reciprocal relationship between tarekat leaders and the Timuriyya dynasty's rulers. The dissemination of the Tarekat Naqshabandiyya network became a link between groups that were connected through the spiritual ties of the tarekat with one another, so that spiritual ties became part of strengthening the expansion of the Tarekat Naqshabandiyya as an influential tarekat in the Islamic world. The development of the Tarekat Naqshabandiyya had an influence on the network and the emergence of variants from among the Naqshabandiyya networks, which showed that the tarekat gave wide space for murshids to develop their respective networks.

The extensive development of the Tarekat Naqshabandiyya network also reinforces the variants following the changing times and

\footnotetext{
${ }^{1}$ N. Hanif, Biographical Encyclopedia of Sufis: South Asia (New Delhi: Sarup and Sons, 2000), 258.

2 Abdelfattah Mohsen Badawi, A Journey to Self-Peace (USA: Trafford Publishing, 2012), 18.
} 
understanding of its followers. Muhammad b. 'Abd al-Karīm alKisnazan al-Husaynī stated that the Tarekat Naqshabandiyya was divided into several parts, namely the Tarekat Naqshabandiyya alMujaddadiyya, the Tarekat Naqshabandiyya al-Zubayriyya, the Tarekat Naqshabandiyya al-Mutahhiriyya, the Tarekat Naqshabandiyya alZubairiyya al-'Âlamiyya, and the Tarekat Naqshabandiyya alMurādiyya. ${ }^{3}$ Meanwhile, according to Muhammad al-Khan̄in, the Tarekat Naqshabandiyya was also divided into the Tarekat Naqshabandiyya Ahrariyya which went along with Shaykh Ahmad alFaruqī Sirhindī. In the background, the Tarekat Ahrāriyya changed to the Tarekat Naqshabandiyya Mujaddadiyya, the Tarekat Naqshabandiyya Muzhariyya, and the Tarekat Naqshabandiyya Khālidiyya. ${ }^{4}$

The variant that emerges from the Tarekat Naqshabandiyya shows the tarekat is open to the murshid's renewal process. So, that variants appear always associated with the name of the character, or murshid who developed the tarekat. According to Martin van Bruinessen, in Mecca in the $17^{\text {th }}$ and $18^{\text {th }}$ centuries, there were three schools of the Tarekat Naqshabandiyya, namely the Tarekat Naqshabandiyya Khālidiyya, the Tarekat Naqshabandiyya Muzhariyya, and the Tarekat Naqshabandiyya Qādiriyya. ${ }^{5}$ The Tarekat Naqshabandiyya continues to grow and divide into various parts of the world. Particularly in Indonesia, apart from splitting into the three schools mentioned by the Tarekat Naqshabandiyya, it also split into the Tarekat Naqshabandiyya Mujaddadiyya. ${ }^{6}$ Furthermore, according to Warner Kraus, the Tarekat Naqshabandiyya also broke into one other

\footnotetext{
3 Muhammad b. 'Abd al-Karīm al-Kisnazan al-Husaynī, Mawsu'at al-Kisnazan fi mā Istalahā 'alayh Abl al-Tasawmuf wa al-Irfän, Vol. 14 (Suriah: Dar al-Maḥabbah, 2005), 133.

4 'Abd al-Majīd bin Muhammad al-Khan̄i, al-Hadāiq al-Wardìyah fì Haqãiq Ajlai alNaqshabandìyah (Irbil: Wizārat al-Tarbìyah, 2002), 13.

5 Martin van Bruinessen, "The Origins and Development of Sufi Orders in Southeast Asia", Jurnal Islamika, Vol. 21 (2016), 150-154; W. Muh. Shagir 'Abdullah, Syekh Ismail al-Minangkabawi Penyiar Tharekat Naqsyabandiyah Khälidiyya (Solo: Ramadani, 1985), 107, Hamid Algar, "The Naqsabandi Order: A Preliminary Survei of Its History and Significance”, Studia Islamica, Vol. 44 (1976), 149-151.

${ }^{6}$ Martin van Bruinessen, Tarekat Naqsyabandiyah di Indonesia (Bandung: Mizan, 1993), 54-59.
} 
form, namely the Naqshabandiyya-Sammāniyya Tarekat of merging between Naqshabandiyya and Sammāniyya. ${ }^{7}$

So far, it has been recorded that among the Tarekat Naqshabandiyya, which has a major influence, namely the Tarekat Naqshabandiyya-Khālidiyya Tarekat (TNK). The TNK is part of the Naqshabandiyya, which has developed massively in Indonesia, especially through the path of Sulaymān al-Zuhdī, or his son 'Ali Rida is popularly referred to as "Shaykh Jabal Abi Qubis." The murshid who connected TNK to students from Indonesia and other countries while studying in Mecca. Apart from that, another TNK network that developed in Indonesia was also found through the network of Khalil Hamdi Basya and his son Hilmi Khalil Hamdi, known as the Jabal Hindi stream. The two Tarekat Naqshabandiyya networks are said to have a history of conflict over the struggle for spiritual authority, which not only involved the murshid developers of the tarekat, but also involved students who continued teaching and practicing in the holy land, Mecca to Indonesia as the area that received the most of the TNK lineage.

Related research has focused more on the Tarekat Naqshabandiyya Jabal Abi Qubis (TNJAQ) network. In contrast, the Jabal Hindi Tarekat Naqshabandiyya (TNJH) network has hardly been found. However, traces of conflict over the struggle for spiritual authority between the two are evident in developing TNK in Indonesia. TNJH has not received much attention from researchers, even though this tarekat is scattered, but its traces are rather challenging to find. So, TNJH in North Sumatra is important for more in-depth exploration, especially regarding efforts to show other variants of TNK as a non-mainstream group of TNJAQ in Indonesia through references from North Sumatra. Throughout the researcher observations and observations in Medan and its surroundings, five places where the tarekat affiliated with TNJH have developed with thousands of followers. Researchers tried to find references about TNHJ through printed or electronic references. However, the researchers have not found adequate information so far, except for only a glimpse of Bruinessen's book on the Tarekat Naqshabandiyya

\footnotetext{
${ }^{7}$ Warner Kraus, "Some Notes of Introduction of The Naqsabandiyah Khālidiyya Into Indonesia", in Marc Gaborioeau, et.al. (ed.), Naqshabandis Cheminemens et Situation Actulen d'un Ordre Mystque Musulman (Istanbul: ISIS, 1990), 691.
} 
in Indonesia. ${ }^{8}$ Departing from the fact that there is a lack of studies on the TNJH, the researcher tries to describe the relevant TNJH to add references to the Tarekat Naqshabandiyya in Indonesia, especially seeing the struggle for authority, which is still dead until now.

\section{The Struggle of Spiritual Authority}

TNJH emerged against the background of a struggle for spiritual authority between Sulaymān al-Zuhdī and Khalil Hamdi Basya in the holy land, Mecca city, around the end of the 19th century AD. The two figures were said to be involved in conflicts related to authority in continuing the leadership of the tarekat in Jabal Abi Qubis as the basis for TNK. Both of them had the same potential to occupy this position because they were both caliphs who had the opportunity and spiritual authority to become TNK murshid. However, both see it is important to occupy a position as a student as part of efforts to develop TNK throughout the world, including Indonesia, as the country that has visited Mecca the most to study. The conflict over authority did not find common ground until, eventually, there was a split between the two. Martin van Bruinessen noted the ongoing conflict over spiritual authority as a conflict over spiritual legitimacy in the leadership of TNK as a tarekat that has a strong influence in Muslim society.

It is said that the conflict between Sulaymān al-Zuhdī and Khalil Hamdi arose when 'Abd Allāh al-Jinjānī appointed Yahyā Dagistanī as his caliph. Dagistanī is the son of Sulaymān al-Zuhdī. With this appointment, Abd Allāh alJinjānī made three people, namely Sulaymān al-Zuhdī, Khalil Hamdi Basya, and Yahyyā Dagistanī as his caliph. After 'Abd Allāh al-Jinjānī passed away, there was a competition between them. Namely, on the one hand, Sulaymān al-Zuhdī and his son Yahyā Dagistanī against Khalil Hamdi had the title Pasya (as a sign that he was a person who had held a high position in the Ottoman empire government). The competition between them is a race to exert influence on Indonesian pilgrims who live in Mecca, which, according to Snouck Hurgronje, is very profitable economically. ${ }^{9}$

The conflict over spiritual authority between Sulaymān al-Zuhdī and Khalil Hamdi Basya occurred in several chapters that involved

\footnotetext{
${ }^{8}$ Bruinessen, Tarekat Naqsyabandiyah, 18.

${ }^{9}$ Ibid., 71.
} 
both of them claiming each other. Khalil Hamdi Basya, as a party close to the ruler. At that time, he managed to win the first stage competition. However, Sulaymān al-Zuhdī did not accept his defeat, so he devised a strategy to counterattack Khalil Basya in his way, namely Sulaymān al-Zuhdī sending treatises to various parts of the world, including Indonesia. The treatise contents explain that the tarekat led by Hamdi Basya has deviated from the primary doctrine of the Tarekat Naqshabandiyya because it combines elements of erotic dance and music in the process of gaining spiritual passion. Sulaymān al-Zuhdî̀s strategy turned out to be successful because the treatises he sent to various parts of the world were effective and succeeded in seizing the influence of Khalil Hamdi Basya. Sulaymān al-Zuhdī’s treatise caused the followers of Khalil Hamdi Basya to start leaving his teachings slowly. Compared with the followers and jam $>a^{6} a b$ of Sulaymān al-Zuhdī, Khalil Hamdi Basya no longer has a strong following in Muslim society. ${ }^{10}$

Sulaymān al-Zuhdī victory in the struggle for spiritual authority established him as the ruler of the zawiya 'Abd Allāh al-Jinjānī on the hill of Abī Qubays. ${ }^{11}$ From that victory, Sulaymān al-Zuhdī was known as "Shaykh Jabal Abī Qubays" or popularly known in Indonesia as Jabal Qubis or Tarekat Naqshabandiyya Jabal Abi Qubais (TNJAQ). ${ }^{12}$ As for Khalil Hamdi Basya as the loss, he finally left zawiya 'Abd Allāh al-Jinjānī. Then, as a counterpoint, he also established a new zawiya in Jabal Hindi ${ }^{13}$ as a differentiator from Jabal

${ }^{10}$ Sulaiman al-Zuhdī is also known as Sulayman Efendi or Sulayman Pasha. Michael Laffan, The Making of Indonesian Islam: Orientalism and the Narration of a Sufi Past (Princeton: Princeton University Press, 2011), 51.

$11 \mathrm{Jabal}$ Abī Qubays is a mountainous or hilly area in Mecca, located to the east of the Grand Mosque. Jabal Abī Qubays was a village where shaykhs and students who studied religion lived. However, at present, Jabal Abì Qubays has become the King of Saudi Arabia and Guesthouse palace complex, which were built by five-star hotels where guests and heads of state stay.

12 Muhammad Khairi Mahyuddin, et.al., "The Arrival of Naqshabandi Order from Hijaj to the Malay World: $16^{\text {th }}$ until the Early 19th Century", International Journal of Business and Social Science, Vol. 4, No. 1 (2013), 211; Bruinessen, Tarekat Naqsyabandiyah, 72.

13 Jabal Hindi or known as Jabal Qaiqu'an (Qua'iqu'an), is located south of the Grand Mosque. The mountainous area has many names, including Jabal al-'Abadī, Jabal al-Sulaymānìyah, and Jabal al-Sūdān. The word "Hindi" in the name of the mountain indicates Indian society's existence in Mecca in pre-Islamic times. Families with Indian ancestry can be found throughout the Gulf Coast, in cities such as Buraydah and Uniyzah in the Arabian peninsula's interior, including Mecca, 
Qubis. So, he was finally known as "Shaykh Jabal Hindi" or Shaykh Tarekat Naqshabandiyya Jabal Hindi. In another story, it is said that he went from Mecca to meet his students to strengthen influence among his jamáa $a{ }^{14}{ }^{14}$ Snouck Hurgronje mentioned another story because of the conflict between Sulaymān al-Zuhdī and Khalil Hamdi Basya that around 1885, the two figures had the most students from Indonesia. Both of them were very clever and shrewd in luring Indonesian pilgrims to become followers of the Tarekat Naqshabandiyya. They both live in Jabal Abì Qubays. It's just that Sulaymān al-Zuhdī or Sulayman Efendi is better known as Shaykh Jabal or Shaykh Jabal Abī Qubays, rather than Khalil Hamdi, who is more often called Pasya because of his closeness to the Turkish government at that time. ${ }^{15}$ Both of them could declare themselves as the next generation of zawiya 'Abd Allāh al-Jinjānī. Sulaymān alZuhdi position as a person with the title Shaykh Jabal is profitable. Likewise, Khalil Hamdi Basya could claim to be Shaykh Jabal Abī Qubays because he was a senior and very close to the ruler at that time in zawiya. Khalil Hamdi Basya also stated that he was the closest person to Shaykh al-Jinjānī because he had served the Shaykh for seven years. ${ }^{16}$

In the end, there was a very fierce conflict between Sulaymān al-Zuhdī and Khalil Hamdi Basya because each accused each other of being heretical and deviating from the actual teachings of the Tarekat Naqshabandiyya. In this conflict, Sulaymān al-Zuhdī wrote and sent treatises to all the regions and areas that were based on the Naqshbandiyya Order, which stated that Khalil Hamdi Basya had combined wild music and dances to achieve spiritual happiness. With this treatise, Khalil Hamdi Basya position as Shaykh of the Tarekat Naqshabandiyya was threatened. Khalil Hamdi Basya then asked for help from his political colleagues, namely the Governor of Hijaz and the Mufti of the madhhab of al-Shāfici, namely Ahmad bin Zayni

\footnotetext{
Medina, and Jeddah. Throughout the centuries, contacts between Indians and Arabs took place in trade relations, even beyond commodity exchanges. Hamid Ansari, "India and the Persian Gulf", Atish Sinha and Madhup Mohta (eds.), Indian Foreign Policy: Challenges and Opportunities (New Delhi: Academic Foundation, 2007), 275.

14 Snouck Hurgronje, Mekek in the Later Part of the $19^{\text {th }}$ Century: Daily Life, Customs and Learning (Leiden: Brill, 2007), 191.

${ }^{15}$ Ibid. Martin van Bruinessen, "The Origins and Development of the Naqshbandi Order in Indonesia”, Der Islam, Vol. 67 (1990), 165.

${ }^{16}$ Bruinessen, Tarekat Naqsyabandiyah, 72.
} 
Dahlan, to force Sulaymān al-Zuhdī to withdraw the treatises he had distributed to various countries. Khalil Hamdi Basya's efforts were successful, and in 1883 he won the conflict between him and Sulaymān al-Zuhdī. ${ }^{17}$

During its development, Sulaymān al-Zuhdī was the winner in the final round of the battle. In terms of quantity, the number of followers of Sulaymān al-Zuhdī continued to increase. In contrast, the followers of Khalil Hamdi Basya continued to decrease because the message sent by Sulaymān al-Zuhdī had spread everywhere. Bruinessen said that Snouck Hurgronje was not happy with the two Shaykhs, so Hurgronje wrote the dispute between Sulaymān al-Zuhdī and Khalil Hamdi Basya with disrespect by placing economic elements as the main reason for the ongoing conflict. Hurgronje stated that worldly interests caused the dispute between the two Shaykhs because pilgrims worldwide, including Indonesia, were very profitable for them as murshids who had many students from various Muslim countries, especially from Indonesia. ${ }^{18}$

Based on the explanation stated, it can be understood that initially Sulaymān al-Zuhdī and Khalil Hamdi Basya were caliphs of 'Abd Allāh al-Jinjānī. They both lived in the zawiya al-Jinjānī in Jabal Abī Qubays. After a conflict over the struggle for spiritual authority between them, which was eventually won by Sulaymān al-Zuhdī, Khalil Hamdi Basya founded a new zawiya called TNJH. This tarekat is a match for the Tarekat Naqshabandiyya based in Jabal Abi Qubays as the base of Sulaymān al-Zuhdī. From the conflict, it was seen that the Tarekat Naqshabandiyya of zawiya al-Jinjān̄ split into two; namely, Sulaymān al-Zuhdī became "Shaykh Jabal Kubis" and Khalil Hamdi Basya became "Shaykh Jabal Hindi". In its development, especially for networks in Indonesia, it is argued that the Tarekat Naqshabandiyya network is influential through the lineage of Shaykh Sulaymān al-Zuhdī. Meanwhile, Khalil Basya network tends to be less obvious in Indonesia, although recently, a tarekat was discovered, which was connected to Khalil Basya by popularizing the name as TNJH.

TNJH, as a counterpart to TNJAQ, has a lot of closeness because both are connected to al-Jinjani as murshid, the two figures representing TNK practitioners. The other side also found

\footnotetext{
${ }^{17}$ Ibid., 69.

18 Ibid.
} 
differences, both of doctrine or rituals practiced by the adherents of the two tarekat because they always tried to differentiate themselves from one another. Practically, even though these two variants of TNK are a group fighting for spiritual authority, the two can grow together, especially at the beginning, which was the choice of the tarekat, which was in great demand by Indonesians who performed Hajj and at the same time deepened the knowledge of religion in the holy land. Through the path of the Indonesian people in Mecca at that time became part of the formation and strengthening of the TNK network in Indonesia because the latter group would later play a role in the expansion of the TNK network in Indonesia. So, that it became a major stream to dominate as a spiritual order in a society whose influence was a strong moment right now.

The conflict between TNJAQ with TNJH did not only occur between tarekat leaders in Mecca but also impacted congregations in Indonesia. Likewise, the conflict has not only left differences among the community. Still, it has also created mutual efforts not to accept one another, even though the conflict has been going on for a very long time. However, traces of conflict continue to emerge as a differentiator between these TNK. Conflicts between congregations are found in North Sumatra, especially among group adherents with mutual claims and other negative assessments. For example, the TNJAQ group considers the TNJH congregation as part of a sect that is not in accordance with the doctrine taught by the TNK murshids because it reduces various aspects of the ritual. On the other hand, the TNJH group is of the view that TNJAQ has made many additions to the tarekat ritual activities that it no longer reflects the original TNK doctrine.

\section{Penetration of TNJH in North Sumatra}

The early history of the penetration and development of TNJH in Indonesia has not found any definite sources because there are not many sources that explain the limited nature of TNJH. In contrast to TNJAQ, which is connected to Sulaymān al-Zuhdī, it has entered and developed since the 19th century. Still, TNJH from the Khalil Hamdi Pasya network only recently emerged in North Sumatra. The difference time directly related to the struggle for spiritual authority between the two leading TNK figures, Sulaymān al-Zuhdī, wins the ongoing struggle for legitimacy. So, the TNJH network does not have 
an adequate place to be accepted and developed in Indonesia. The general narrative TNK generally always refers to TNJAQ as its main reference. The struggle for authority between TNJAQ and TNJH is not visible because the existence of TNJH as a match for TNJAQ does not appear on the surface. Generally, TNK always refers to Sulaymān al-Zuhdī as the murshid who connected his caliph with the people in Indonesia who were widespread in almost all parts of Indonesia.

The penetration of TNJH is thought to have existed in North Sumatra through the relationship between Indonesian students with Khalil Hamdi Basya, namely Zayn al-Nur al-Din (d.1968) connected to 'Abd Allah al-Hilmi, his son of Khalil Hamdi Basya, ${ }^{19}$ who also became continued murshid in Jabal Hindi after Khalil Hamdi. However, the progress of TNJH through Zayn al-Nur is not known whether it developed it or not because, until the research was carried out, there was no found any TNJH network that developed through Zayn al-Nur. Apart from Zayn al-Nur, he was also accompanied by Muhammad Tayyib, a colleague who later became Zayn's father-inlaw when he left for Mecca and connected with his son Khalil Hamdi. However, Tayyib's own figure is not widely known, but he traces are found in the TNJH lineage, as presented in the following discussion. Another source also said that TNJH is also developing in Malaysia, especially in Penang through Muhammad Tayyib (d?). ${ }^{20}$ Still, it is not certain whether Tayyib here is the same as who introduced TNJH in North Sumatra. Tayyib received the lineage of the tarekat from Muhammad Yahya, which is connected to 'Abd Allah al-Hilmi as a successor to murshid in Jabal Hindi. Yahya himself has visited Penang, Malaysia, to strengthen the TNJH network, but the related information is uncertain. Meanwhile, the TNJH network, which originated from Tayyib, was then continued by Jafar Muhammad, but again the tarekat tracks are not known for its subsequent developments. ${ }^{21}$

\footnotetext{
19 Muhammad Zayn, Majmū' Mushtamil 'alā Jumlah Thaläthah Rasāill (Penang: Zi United Quraish, n.d.), 15.

20 Abdul Manan bin Mohammad al-Merbawi, et.al., "Tarekat Naqshabandiyah Khalidiyyah in Malaysia: A Study on the Leadership of Haji Ishaq bin Muhammad Arif', Miqot, Vol. 36, No. 2 (2012), 302.

${ }^{21}$ Bruinessen, Tarekat Naqsyabandiyah, 161.
} 
According to Sahbuddin, ${ }^{22}$ the murshid Pondok Suluk Babu Hikmatillah (PSBH), who is also part of TNJH Paya Geli. TNJH has entered Indonesia, especially North Sumatra, starting with Muhammad Jamil bin Datuk Kanda Maharajo Ibrahim from the Bonjol area, Padang, West Sumatra, in 1925. He came to Paya Geli Village, Deli Serdang, North Sumatra. In that area, he met 'Abd alWahab bin Arab who had the surname Surbakti. When Jamil and 'Abd al-Wahab were about to perform Haji, Muhammad Tayyib ${ }^{23}$ as the spiritual leader, advised them to meet Khalil Hamdi Basya when they arrived in the holy land. When the two arrived in Mecca, they met Khalil Hamdi to study the tarekat, according to Tayyib's suggestion. Then, when they were about to return from Mecca to Indonesia, Jamil and 'Abd al-Wahab also received instructions to deepen the knowledge of Sufism from Tayyib, who was also Khalil Hamdi previous student. Returning to Indonesia, precise in Medan City, the two of them studied for a long time from Tayyib to deepen their knowledge of TNK. So, that finally, Jamil was appointed caliph and ordered to open a TNJH branch in Paya Geli Village, Deli Serdang. ${ }^{24}$

It can be emphasized that the person who first introduced TNJH to Indonesia, especially to North Sumatra, was Tayyib, who was the representative of Khalil Hamdi. As for Jamil and 'Abdul Wahab, they were Khalil Hamdi direct students and were also equipped by Tayyib. However, there was no insufficient information regarding Tayyib figure as far as the research was carried out. Sahbuddin, as the continuation of the TNJH leadership, said that he had never met him. However, it is certain that in the hut of his grandfather, "Abd al-Wahab, the figure of Tayyib was also known as "Shaykh Uyub". Researchers suspect that the Tayyib referred to by Sahbuddin is Haji Muhammad Tayyib Adis, the father-in-law of Muḥammad Zayn Nūr al-Dīn b. Imām 'Abbās al-Khālidī alNaqshabandī. As stated earlier, Muhammad Zayn is a very respected Sufism scholar, who was born in Pesisir Dahari Selebar, now in

22 Sahbuddin is a murshid the Pondok Suluk Babu Hikmatillah Tarekat Naqshabandiyya Jabal Hindi Paya Geli Deli Serdang North Sumatra in 2020 when this research was conducted. 'Abd al-Wahab bin Arab is his grandfather.

23 According to Sahbuddin, Muammad Tayyib came from Serdang Bedagai.

24 According to Sahbudin, 'Abd al-Wahab bin Arab with Muhammad Jamil studied or recited the tarekat from Muhammad Tayyib by boat passing Sei Mencirim (Mencirim River). 
Talawi District, part of the Batubara area, North Sumatra. ${ }^{25}$ At first, Muhammad Zayn performed the pilgrimage with Tayyib. Upon his return to Indonesia, Muhammad Zayn married Tayyib's daughter, Kemala Intan, who later changed her name to Fatimah bint Haji Muhammad Tayyib after performing the pilgrimage. While in Mecca, Tayyib and Muhammad Zayn both studied with 'Abd Allah al-Ḥilmī b. Khalīl Hamdī Basya b. Yahyā Dagestan. ${ }^{26}$

\section{The Development of The Tarekat Naqshabandiyya Jabal Hindi}

The establishment of TNJH as a spiritual organization in North Sumatra was spearheaded by Muhammad Jamil and 'Abd al-Wahab bin Arab in Kampung Paya Geli, Deli Serdang. According to Sahbuddin, the establishment of the tarekat in Paya Geli was based on orders from Muhammad Tayyib to Muhammad Jamil and 'Abd alWahab. ${ }^{27}$ After Muhammad Jamil got "Shaykh" or murshid title, Tayyib asked him and "Abd al-Wahab to open a TNJH branch. The establishment of the tarekat took place in 1927 in the house of 'Abd al-Wahab, who later became the successor of Muhammad Jamil. After Muhammad Jamil died in 1934, the recitation leadership was continued by 'Abd al-Wahab, who came from the Karo tribe. The lineage of his parents is Pelbegu faith. According to Sahbuddin, when 'Abd al-Wahab returned from performing the pilgrimage, he added his name to bin Arab even though his parents were not of Arab descent or had the name bin Arab. This was a symbol of his break with Pelbegu beliefs and, at the same time, his connection with Arab beliefs, which at that time was the symbol and center of Islam. ${ }^{28}$ During his leadership of TNJH, 'Abd al-Wahab appointed two caliphs, namely the Muhammad Daud (his son) and 'Abd al-Rahman bin Ustman a son of Deli. Muhammad Daud was a high dhawq person, so that he could not carry or lead tawajjuh and suluk (recitation of dhikr). When 'Abd al-Wahab fell ill and died in 1946, the TNJH recitation moved to Tanjung Gusta Village under the leadership of 'Abd al-Rahman bin Uthman.

\footnotetext{
25 Ahmad Fauzi Ilyas, "Pemikiran Fikih Syaikh Muhammad Zain Batubara: Fidiah Salat dan Puasa", Miqot, Vol. 42, No. 2 (2007), 262.

26 Ibid.

${ }^{27}$ Interview with Sahbuddin, Sumatera Utara, April 20, 2020.

28 Pelebegu is an animistic belief in ancestral spirits that developed among the Karo people.
} 
In 1957, 'Abd al-Rahman opened a branch in Kurnia Belawan Village under the tutelage of the Muhammad Said bin Syamsuddin of the same name. This branch cottage conducts recitation at night, while in the afternoon, they have to go to Tanjung Gusta to perform tawajjub under the guidance of 'Abd al-Rahman. According to Fahmi's statement, ${ }^{29}$ this kind of activity continued until 1963, when 'Abd alRahman passed away. After that, the TNJH recitation returned to Kampung Paya Geli. Muhammad Nuh performed the recitation at Paya Geli, even though the murshid was Muhammad Daud. This was due to the heavy dhaw $q$ who came to Lord Shaykh Muhammad Daud, so he could not lead the recitation. When Muhammad Nuh went to perform the haj pilgrimage, the recitation was stopped for several months because he spent so long in Mecca's holy land, while his students always insisted that the recitation be carried out. Then, Muhammad Daud ordered that the recitation be carried out in Belawan, to be precise in the residence of Muhmmad Said bin Syamsuddin from East Java. ${ }^{30}$

In a short time, the recitation was in great demand, so that the house of the Muhmmad Said bin Syamsuddin could no longer accommodate the congregation. Muhammad Said then took the initiative to carry out recitation at the mosque. Still, the general public was disturbed so that there was a small conflict between the congregation and the community around the mosque. Concerned about this situation, one of the recitation congregations donated his land on Jalan Young Panah Hijau, environment III Marelan to be used as a recitation place. The construction of the cottage began in 1977 and was completed in 1978. In that same year, the TNJH recitation program officially moved from Kurnia Belawan Village to Marelan, Medan Labuhan District, Medan. After moving, Muhammad Said changed his name to Pondok Pesantren Babur Ridho TNJH. ${ }^{31}$ On Thursday, November 11, 1988, Muhammad Said passed away and was buried at Jalan Young Panah Hijau, Labuhan Deli Village, Medan Labuhan District, Medan. After his death, TNJH split into several branches, including The TNJH Babur Ridho Islamic Boarding School, led by Muhammad Ishaq bin Haji Muhammad Nurdin,

\footnotetext{
${ }^{29}$ Interview with Fahmi, Sumatera Utara, April 24, 2020.

30 Interview with Sahbuddin, Sumatera Utara, April 20, 2020.

31 Uqbatul Khoir Rambe, "Tarekat di Pesantren Babur Ridho Ahli Tarekat Naqsyabandi Jabal Hindi” (Thesis--Program Pascasarjana, Institut Agama Islam Negeri Medan, 2004), 44-45.
} 
Pondok Pesantren Nurul Hijrah Pekan Labuhan led by Fakhruddin, Gang Pinang Pulau Brayan led by Zainun, and Kurnia Belawan Village leads by Harahap. ${ }^{32}$

In the next generation, from Pondok Pesantren Babur Ridho, TNJH was reborn in Paya Geli, Deli Serdang. The jama'ah was named Pondok Suluk Babu Hikmatillah TNJH with the leader Sahbuddin. He is the caliph of Muhammad Ishaq bin Haji Muhammad Nurdin. Sahbuddin received a mandate from Muhammad Ishaq to revive TNJH in Paya Geli, which was the beginning of all TNJH in North Sumatra. ${ }^{33}$ At the Babur Ridho Islamic Boarding School, after the death of Muhammad Ishaq, the leadership was continued by Hirfi Nuzlan. When this tarekat was under the leadership of Hirfi Nuzlan, TNJH Babur Ridho Islamic Boarding School opened branches in various places, including; DPC Binjai on Jalan Medan-Binjai Km 19, led by Rusdi Mohan; DPC Air Batu Langkat Regency, led by Zaini Sitorus; and DPC Tanjung Selamat, Sidomukti Village, Tanjung Pura, led by Salikun.

At this time, the three TNJH branches were closed due to the death of their respective leaders. Meanwhile, Hirfi Nuzlan himself has moved from Jalan Young Panah Hijau to the Office Junction by establishing a new branch called Pondok Pesantren Babu Rahmatillah (PPBR-TNJH). The reason for Hirfi Nuzlan move from Babur Ridho was an internal conflict between him and the previous teacher children. Hirfi Nuzlan was also accused of heresy on June 8, 2006 (11 Jumadil Awal $1427 \mathrm{H}$ ) by the Indonesian Ulema Council (MUI) of North Sumatra Province the Fatwa Commission. The emergence of heretical claims on the PPBR occurred because of a misunderstanding between the pesantren and the community, resulting in the pesantren being signed by the masses aimed at dissolving the pesantren. ${ }^{34}$ The ongoing conflict was finally strengthened by the existence of a fatwa from the North Sumatra MUI, stating that this sect was heretical. However, after going through a long process, the fatwa was finally revoked because after the investigation process was not found any allegations of heresy in the doctrines and rituals taught by the PPBR with the issuance of a letter explaining the fatwa on February 18, 2010

\footnotetext{
32 Interview with Fahmi, Sumatera Utara, April 24, 2020.

${ }^{33}$ Interview with Hendra, Sumatera Utara, April 24, 2020.

34 The Wahid Institute, Monthly Report on Religious Issues, 26 2010, 1-2.
} 
(4 Rabiul Awal $1431 \mathrm{H}$ ) which contained that this heresy is no longer valid. ${ }^{35}$

In its development, after Hirfi Nuzlan move, PPBR TNJH was led successively by Ibrahim, Uqbatul Khoir Rambe, Nurdin, and Jasadi, who took the lead in 2020. Another development came from the Nurul Hijrah Islamic Boarding School on Jalan Young Panah Hijau, Kelurahan Pekan Labuhan. Fakhruddin originally led this boarding school. After his death, the leadership of this tarekat turned to his son-in-law, Husin. However, because he moved to Batu Bara and established a TNJH branch, the Nurul Hijrah Islamic Boarding School was continued by Sofyan. In Medan, this order has opened several branches, namely in the Bagan Belawan area and at Pasar 7 Kelurahan Tangkahan, Medan Labuhan District, Medan. According to Caliph Sofyan, the rapid development of this tarekat took place in Batubara with thousands of congregations. Apart from the sites mentioned, the researchers also often saw signs that read TNJH in the Hamparan Perak City, on the Sumatra and Asahan crossing, in Sidempuan towards Panyabungan, the causeway between Sibolga and Parapat. The authors do not know where the TNJH exists in the places mentioned. ${ }^{36}$

From the description stated, it can be understood that TNJH is widely spread in North Sumatra. Starting from Paya Geli Village to Tanjung Gusta Medan, then to Belawan, Marelan, and Brayan Island Medan. Some of these orders then spread to Binjai City, Air Batu Langkat, Tanjung Slamat, Tanjung Pura, and Batu Bara. Furthermore, the Tarekat Naqshabandiyya can also be seen, although only the signs are in the area of Hamparan Perak, Kisaran, Padang Sidempuan, and the causeway between Sibolga and Parapat. The number of TNJH followers is thousands of people, according to each leader the author met. It's just that the presence of these followers in recitation numbered only tens to hundreds of people. This is because the people who have taken the bay'at always come and go, and they are not asked or forced to always be present in every recitation.

TNJH itself can be grouped as a tarekat that is mu'tabarah through has a Shaykh sanad or murshid continued up to the Prophet

\footnotetext{
35 "Fatwa MUI Sumut Telah Dicabut" dalam "http://www.babur-ridhorahmatullah.com/post/Accessed on 5 June 2020.

36 The signs that read the Tarekat Naqshabandiyya Jabal Hindi are often found in various places. Therefore, this paper still needs to be supplemented by conducting research evenly in North Sumatra.
} 
Muhammad. In the tarekat tradition, genealogy is very central because it becomes the basis for the legitimacy of the doctrines and rituals practiced in it. The TNJH lineage, when connected with the lineage that originates from Baha' al-Din al-Naqsabandi as the founder to Shaykh Khalil Hamdi Basya in the holy land, city of Mecca. If the lineage is connected with the TNJH lineage after arriving in Indonesia, especially Paya Geli, Deli Serdang, North Sumatra.

1. Prophet Muhammad

2. Abū Bakr Siddīq

3. Salmān al-Fārisī

4. Qāsim b. Muhammad

5. Ja'far a-Sādiq

6. Abū Yazìd al-Bistāàmī

7. Abu Hasan al-Kharaqānī

8. Abū A' lā al-Farmajī

9. Abū Ya'qūb Yūsuf al-Ḥamadānī

10. 'Abd al-Khāliq al-Ghujdawan̄̄

11. 'Ārif al-Riwigan̄i

12. Maḥmūd Injirī Fakhnarī

13. Azizan al-Rimitun

14. Muhammad Bāba al-Samasī

15. 'Āmir Kulāl

16. Bahā' al-Dīn al-Naqshaband

17. Yakūb Cargi

18. Ubaydillāh al-Aḥrār

19. Ahmad Amkinagi

20. Baqi Billāh

21. Ahmad Faruqī Sirhind̄̄

22. Muḥammad Ma'șum

23. Sayyed Diyā al-'Ārif

24. Mirza Mazhar Jan’i Janan

25. Shaykh 'Abd Allāh (Gulam 'Ali)

26. Khalid Diya al-Dīn

27. 'Abd Allāh al-Jinjān̄̄

28. Khalil Hamdi Basya

29. Muhammad Tayyib

30. Muhammad Jamil

31. 'Abd al-Wahab bin Arab

32. Abdurrahman bin Usman 


\section{Muhammad Daud}

34. Muhammad Said bin Samsuddin

35. Muhammad Ishaq bin Haji Muhammad Nurdin

From the lineage of Muhammad Said bin Samsuddin, TNJH will later spread to Sumatra's various regions, as previously mentioned. For PPBR TNJH, it was continued by Mr. Shaykh Muhammad Ishaq bin Haji Muhammad Nurdin. The TNJH lineage appears to be a link generally connected among TNK, both from the Sulaymān al-Zuhdī line or others, only different lineages from Khalil Hamdi Basya down to the bottom. The TNJH lineage is a lineage that mu'tabarah follows the lineage accepted as a tarekat with a clear teacher chain from the Prophet Muhammad to the current murshid.

\section{The Doctrine of TNJH on Dhikr}

The main doctrine of TNJH is dhiker to Allah, which the followers interpret as "remembering Allah." In this tarekat, dbiker or remembering is the primary teaching. ${ }^{37}$ According to Sahbuddin, remembering Allah in the heart is the first obligation before the Sharia is compulsory. The normative argument from Q.S. al-A'tā [87]: 14-15:

$$
\text { قَذْ أَفْحَح مَنْ تَزَّكَى وَذَكَرَ اسْمَ رَبِّهِ فَصَلَّى }
$$

He is successful who groweth and remembereth the name of his Lord, so prayeth.

Another rationale on which TNJH is based on establishing dbikr as its main teaching is the hadith of the Prophet Muhammad, which states: ${ }^{38}$

$$
\text { اول الدين معرفة الله }
$$

The beginning of religion is knowing Allah.

According to the belief of the followers of this tarekat, that whatever human deeds are done without dbiker, there will be no meaning to Allah. Humans in their actions are only divided into two groups, namely those who do something together and those who are not with God. People who do something with Allah, then whatever

\footnotetext{
${ }^{37}$ Rahmawati, et.al., "Makna Zikir Bagi Jemaah Tarekat Naqshabandīyah Khālīdīyah Majelis Pengkajian Tauhid Tasawuf Indonesia di Kota Gorontalo", Teosofi: Jurnal Tasawnf dan Pemikiran Islam, Vol. 8, No. 2 (2018), 328.

38 Mustafa Zahri, Kunci Memahami Ilmu Tasauf (Surabaya: Bina Ilmu, 1979), 131; Muhammad Saleh bin 'Abdilah, Rahasia Agama dan Tasauf (Surabaya: Yayasan Dakwah Islam, 1981), 16.
} 
their deeds will be judged good by Allah. On the other hand, a person who does something without being with Allah, his actions will not be seen by Allah as a good thing even though he is performing prayers, zakat, pilgrimage, and so on. According to several caliphs such as Sukari Zamanno, Muhidi, and Syafruddin that knowing Allah is the first teaching exemplified by the Prophet Muhammad. Before teaching shari'a, the Prophet Muhammad first sought to know about God. This practice is recorded in the tahannus (seclusion to place the soul) which the Prophet practiced in the hill of hira. After the Prophet knew God in truth, then he left to spread the teachings of Islam, including prayer, fasting, zakat, and other. ${ }^{39}$

In the TNJH doctrine, knowing God is the foremost teaching. In order to know Allah, humans must silently chant His name. Chanting Allah in the heart is useful. So, that human activities are not disturbed to carry out various humanitarian tasks on earth, and at the same time it is a manifestation of Q.S. al-Nisā [4]: 103.

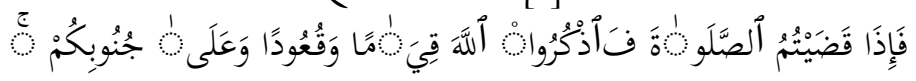

So, (O Muslims,) when you have finished your Prayer, remember Allah (in all postures:) standing, sitting, and (lying down) on your sides.

According to TNJH followers, remembering Allah can be done even when you are sleeping. People who have reached this stage have been in the "grip" of Allah, and all their activities have been under God control. Humans must perform riyadah (soul training) and tazkiyat al-nafs (soul purification) to reach this stage. One of the initial stages in soul purification in the view of TNJH is repentance. Repentance aims to purify the soul from a character that is not praiseworthy. People who repent are expected to have implications for their behavior in everyday life, whether related to God, humans, or the environment. ${ }^{40}$

According to $\mathrm{TNJH}$, soul purification requires the implementation of a series of methods. ${ }^{41}$ First, there are two main points of purifying the human soul, namely chanting the name (asma $)$ of Allah in the heart and remembering Allah in mind. These two main points are called dhikr. The relationship between mentioning and

39 Zahri, Kunci Memahami, 45.

40 M. Sholeh Hoddin, "Konsep Taubat Tarekat Naqshabandîyah Muzharîyah", Teosofi: Jurnal Tasawnf dan Pemikiran Islam, Vol. 2, No. 1 (2012), 38.

${ }^{41}$ Interview with Sahbuddin, Sumatera Utara, April 20, 2020. 
remembering is the same as the relationship between heart and mind. These two things cannot be separated in the journey of taqarrub (closer to oneself) to Allah. A person who has tried to get closer to Allah with his heart alone will not be able to get to Allah. On the other hand, a person who tries to remember Allah with his mind without remembrance in his heart will also not produce true closeness to God. This can happen because mentioning in the heart will create a feeling of love, longing, happiness, peace, peace, and wisdom. To know Allah must be accompanied by remembering in the human mind to get to ma'rifah (knowledge of God). Remembering Allah, in the view of TNHJ, is to carry out all God commands and stay away from all His prohibitions. As for remembering Allah with reason, it will give birth to Him knowledge with real knowledge. So, to get to Allah, the combination of dhikr al-qalb and dhikr al'aql is the main requirement in walking on the journey to get closer to Him and is also the primary requirement in the process of soul purification.

For TNJH, the mind (knowledge of God) must be shown by the divine light residing in the human heart. Someone can't come to ma'rifah to God without a mind and heart. Both are ways for humans to learn and become familiar with God. However, behind these two things, the main key is the quantity and quality of worship. Both institutions will be useless without human acts of prayer, especially the remembrance of Allah. The second method regarding purification of the soul is to do pious deeds, such as praying, doing tasbih, fasting, reading the al-Qur'àn, doing seclusion, tawajjuh, and so on. More than that, reducing sleep at night by doing various Sunnah practices is also a good medium for soul purification for humans. The third method is to think about all of God's creations because many words of God encourage humans to use their minds in understanding His creation. The commandment to believe about God creation is nothing but so that humans will know their Lord. Knowing Allah will create affection and love for Him. Compassion and love for Allah are half the journey towards ma'rifah to Allah. For a sälik, this is already a high state because he has entered the realm of nature to the realm of ma'rifah. Fourth, it is ma'unah (help) of Allah. There are certain people who are deliberately sanctified by Allah because they have been chosen to connect Allah word to explain Himself to humans. Events like this, according to him, can be seen in the person of the Prophet Muhammad, who, as a child, had his chest cut open to remove the 
dirt in his heart. Unlike the Prophet Ibrahim, whose journey to know God through the mind, namely through the exploration of the mind to the stars, moon, and sun. The story of the Prophet Ibrahim is an indicator that shows that by means of the human mind, it can also cleanse the soul. Like the Prophet, who finally submitted when God saw His greatness. ${ }^{42}$

\section{Concluding Remarks}

From the presentation of the history of development and the TNJH doctrine in North Sumatra, it can be confirmed that this tarekat is one of the Tarekat Naqshabandiyya sects from the path of Shaykh Khalil Hamdi Basya. The main pioneers of TNJH in North Sumatra were Muhammad Jamil and 'Abd al-Wahab in Paya Geli Village, Deli Serdang, North Sumatra around 1927-1928. The two founders of the TNJH branch studied from Khalil Hamdi Basya in the holy land, Mecca and Muhammad Tayyib in Serdang Bedagai. The tarekat spread and influence are quite extensive in North Sumatra. The tarekat has thousands of followers or congregations according to their respective branch leaders, which are scattered in various cities in North Sumatra, such as Medan, Binjai, Deli Serdang, Asahan, Tanjung Pura, Sidempuan, and Langkat. Meanwhile, the main doctrine of TNJH primaries the balance of dhiker al-qalb and dhiker al'aql by mentioning Allah and paying attention to its creation in the process of tarkizyat al-nafs.

\section{References}

\section{A. Book/Journal}

'Abdilah, Muhammad Saleh bin. Rahasia Agama dan Tasauf. Surabaya: Yayasan Dakwah Islam, 1981.

'Abdullah, W. Muh. Shagir. Syekh Ismail al-Minangkabawi Penyiar Tharekat Naqsyabandiyah Khälidiyya. Solo: Ramadani, 1985.

Algar, Hamid. "The Naqsabandi Order: A Preliminary Survei of Its History and Significance", Studia Islamica, Vol. 44, 1976.

al-Merbawi, Abdul Manan bin Mohammad et.al. "Tarekat Naqshabandiyah Khalidiyyah in Malaysia: A Study on the Leadership of Haji Ishaq bin Muhammad Arif', Miqot, Vol. 36, No. 2, 2012.

${ }^{42}$ Ibid. 
Ansari, Hamid. "India and the Persian Gulf", Atish Sinha and Madhup Mohta (eds.), Indian Foreign Policy: Challenges and Opportunities. New Delhi: Academic Foundation, 2007.

Badawi, Abdelfattah Mohsen. A Journey to Self-Peace. USA: Trafford Publishing, 2012.

Bruinessen, Martin van. "The Origins and Development of Sufi Orders in Southeast Asia", Jurnal Islamika, Vol. 21, 2016.

----. "The Origins and Development of the Naqshbandi Order in Indonesia", Der Islam, Vol. 67, 1990.

-----. Tarekat Naqsyabandiyah di Indonesia. Bandung: Mizan, 1993.

"Fatwa MUI Sumut Telah Dicabut" dalam "http://www.baburridho-rahmatullah.com/post/Accessed on 5 June 2020.

Ḥusaynī (al), Muhammad b. 'Abd al-Karīm al-Kisnazan. Mawsu'at alKisnazan fì mà Istalahạa 'alayh Abl al-Tașawnuf wa al-Irfän, Vol. 14. Suriah: Dar al-Mahabbah, 2005.

Hanif, N. Biographical Encyclopedia of Sufis: South Asia. New Delhi: Sarup and Sons, 2000), 258.

Hoddin, M. Sholeh. "Konsep Taubat Tarekat Naqshabandîyah Muzhariyah", Teosofi: Jurnal Tasawuf dan Pemikiran Islam, Vol. 2, No. 1, 2012.

Hurgronje, Snouck. Mekka in the Later Part of the $19^{\text {th }}$ Century: Daily Life, Customs and Learning. Leiden: Brill, 2007.

Ilyas, Ahmad Fauzi. "Pemikiran Fikih Syaikh Muhammad Zain Batubara: Fidiah Salat dan Puasa", Miqot, Vol. 42, No. 2, 2007.

Khan̄i (al), "Abd al-Majīd bin Muhammad. al-Hadäiq al-Wardīyah fì Haqāiq Ajlai al-Naqshabandīyah. Irbil: Wizārat al-Tarbīyah, 2002.

Kraus, Warner. "Some Notes of Introduction of The Naqsabandiyah Khālidiyya Into Indonesia", in Marc Gaborioeau, et.al. (ed.), Naqshabandis Cheminemens et Situation Actulen d'un Ordre Mystque Musulman. Istanbul: ISIS, 1990.

Laffan, Michael. The Making of Indonesian Islam: Orientalism and the Narration of a Sufi Past. Princeton: Princeton University Press, 2011.

Mahyuddin, Muhammad Khairi et.al., "The Arrival of Naqshabandi Order from Hijaj to the Malay World: $16^{\text {th }}$ until the Early $19^{\text {th }}$ Century", International Journal of Business and Social Science, Vol. 4, No. 1, 2013.

Rahmawati, et.al., "Makna Zikir Bagi Jemaah Tarekat Naqshabandīyah Khālīeīyah Majelis Pengkajian Tauhid Tasawuf 
Indonesia di Kota Gorontalo", Teosofi: Jurnal Tasawuf dan Pemikiran Islam, Vol. 8, No. 2, 2018.

Rambe, Uqbatul Khoir. "Tarekat di Pesantren Babur Ridho Ahli Tarekat Naqsyabandi Jabal Hindi". Thesis--Program Pascasarjana, Institut Agama Islam Negeri Medan, 2004.

The Wahid Institute, Monthly Report on Religious Issues, 26 2010, 1-2.

Zahri, Mustafa. Kunci Memahami Ilmu Tasauf. Surabaya: Bina Ilmu, 1979.

Zayn, Muhammad. Majmū' Mushtamil 'alā Jumlah Thaläthah Rasāill. Penang: Zi United Quraish, n.d.

\section{B. Interview}

Interview with Fahmi. Sumatera Utara, April 24, 2020.

Interview with Hendra. Sumatera Utara, April 24, 2020.

Interview with Sahbuddin. Sumatera Utara, April 20, 2020. 